\title{
Effect of Ultra-Dry Storage of Chilli Seeds
}

\author{
Ninganna, J.S. Hilli* and B.S. Vyakaranahal \\ Department of Seed Science and Technology, College of Agriculture, \\ University of Agricultural Sciences, Dharwad-580005, Karnataka (India) \\ *Corresponding author
}

\section{A B S T R A C T}

\section{Keywords}

Chilli seeds,

Desiccants, Drying,

Hermetic container,

Moisture, Ultra-dry,

Storage

\section{Article Info}

Accepted:

20 November 2018

Available Online:

10 December 2018
The storage experiment was conducted to know the effect of ultra-dry seed storage of chilli. The experiment was conducted during the period from July, 2017 to March, 2018.The experiment involved storage of chilli seeds with three desiccants viz., zeolite beads, bentonite granules and activated charcoal granules. The experiment was laid out in completely randomized design with four treatments in five replications. Among the four different desiccants, zeolite beads recorded highest germination $(85.60 \%)$, seedling vigour index (1097), dehydrogenase activity (1.149 OD values) and maintained the lowest moisture content $(4.00 \%)$, electrical conductivity $\left(0.709 \mathrm{dSm}^{-1}\right)$, Whereas, the seeds stored in without desiccants deteriorated rapidly in all the seed quality parameters and recorded the lowest germination (75.40\%), seedling vigour index (753), dehydrogenase activity (0.924 OD values) and higher moisture content $(9.65 \%)$, electrical conductivity (0.874 $\mathrm{dSm}^{-1}$ ) at the end of nine months of storage period.

\section{Introduction}

Chilli is one of the most important and the largest produced spice crops in Asia. India is the largest producer, consumer and exporter of chilli. Commercial cultivation of chilli is very much successful and one can expect decent profits in chilli farming due to its market value in local areas and international markets (export market). India is having an area of 287 thousand ha with a production of 3406 thousand tonnes (Anon, 2017).

Ultra-dry seed storage, also called low moisture content storage, it is the technique for decreasing seed moisture content to below 5-6 per cent using desiccants which is stored hermetically at ambient, but preferably cooler temperatures. Some studies have confirmed that low moisture content storage can not only be used to maintain the quality of seeds, but also improve their storability (Wang et al., 2005). It can greatly reduce the cost of constructing and maintaining the gene bank (Zheng et al., 1998). Ultra-dry seed storage technology is the one of an ideal method to store the seeds for longer period by using desiccants in an air tight container without seed quality reduction. Hence, it is a suitable technology to low volume seeds, seed 
companies and seed banks to store precious seed material for a longer period. Desiccant is a hygroscopic substance that induces or sustains a state of dryness (desiccation) in its vicinity. The most common desiccant was zeolite beads, silica and other common desiccants include activated charcoal, bentonite, calcium sulphate, and calcium chloride.

Generally seeds are dried under the sun, if the crop is harvested during rainy season or under cloudy weather it is very difficult to dry the seeds. In such condition, high temperature and humidity combine to cause rapid deterioration of seeds under ambient conditions of storage resulting in poor seed quality, poor plant stand establishment, lower productivity and disincentive to invest in improved seeds. Seed longevity is reduced to approximately half of every one per cent increase in seed moisture content (water content as per cent of fresh weight) or $10^{\circ} \mathrm{F}$ decrease in storage temperature double the storage life of seed and the effects are additive (Harrington, 1972). This principle implies that seed storage life of orthodox seeds can be enhanced considerably by lowering both moisture content and temperature. Cold storage is expensive and difficult to maintain because the electricity supply are often erratic and inconsistent in our areas. In addition, seeds that are dried to low moisture content are more tolerant to storage at warm temperature. However, prolonged sun drying in high humidities cannot reduce seed moisture content to the low level enough to assure long-term viability.

Delay in drying or slow drying together with high temperature (above $25^{\circ} \mathrm{C}$ ) will tend to reduce viability considerably in orthodox seeds. The recommended methods for safe seed drying to a very low moisture content using seed drying chambers or seed dryers, where the relative humidity of the drying environment is controlled (Ellis et al., 1995).
Keeping all above factors in consideration the present investigation was planned to know the effect of ultra-dry storage of chilli seeds during storage with an objective to study the seed quality parameters of chilli seeds under ultra-dry storage condition.

\section{Materials and Methods}

The storage experiment was conducted in the Seed Quality Research Laboratory of National Seed Project, Seed unit, College of Agriculture, Dharwad, to know the effect of ultra-dry seed storage of chilli. The required quantity of desiccants was calculated based on their adsorption capacity to reduce to safe level seed moisture content. Initial moisture content of chilli seeds were 8.5 per cent and stored. Quantity of desiccants stored in chilli was $0.21 \mathrm{~kg}$ for zeolite beads (as per Rhino Research table) and one kilogram bentonite and five kilograms activated charcoal per kilogram of chilli seeds, respectively. The seeds were then mixed with the desiccants and kept in hermetic container and stored for nine months under control condition from July, 2017 to March, 2018. The experiment included four treatment viz., $\mathrm{T}_{1}$ : Chilli seeds stored with Zeolite beads, $\mathrm{T}_{2}$ : Chilli seeds stored with Bentonite granules, $\mathrm{T}_{3}$ : Chilli seeds stored with Charcoal granules, $\mathrm{T}_{4}$ : Chilli seeds stored without desiccant under controlled condition as control. Relative humidity and temperature present in the hermetic container was noted by using EXTECH Hygro-thermometer with direct readings. These hygro-thermometers placed in each hermetic container and readings were noted $24 \mathrm{~h}$. interval throughout the storage period.

The Seed germination percentage was worked out as per the procedure given by ISTA (Anon., 2014), seedling vigour index was worked out as per the formula given by Abdul-Baki and Anderson (1973), Moisture 
content (Anon., 2014), electrical conductivity of seed leachate by Presley (1958) and Dehydrogenase enzyme activity by Kittoch and Law (1968). The data of the laboratory experiment were analyzed statistically by the procedure prescribed by Gomez and Gomez (2010).

\section{Results and Discussion}

\section{Germination}

The loss of germination and vigour of seed during storage is an inevitable metabolic process. These losses occur in storage due to many factors such as moisture content, temperature, relative humidity, length of storage period and storage containers (Singh et al., 1988). These factors have been discussed in detail by Roberts (1972). The initial germination per cent (94.00) was observed in case of chilli seeds cv. Byadagi kaddi. The seed germination percentage was above seed certification standards $(60 \%)$ in all treatments (Table 1). The seeds stored with zeolite beads $\left(\mathrm{T}_{1}\right)$ have shown significantly highest germination per cent (85.60) and was on par with the seeds stored with bentonite granules $\left(\mathrm{T}_{2}\right)(84 \%)$ followed by seeds stored with activated charcoal granules $\left(\mathrm{T}_{3}\right)(82.8 \%)$. All the desiccants showed significant effect with respect of chilli seeds to germination per cent after six months of storage (Table 1). The retention of high seed viability with desiccant might be due to slow lowering of seed moisture at ultra dry conditions i.e., by zeolite beads and bentonite granules during storage which resulted on low seed respiration and maintenance of cell membrane integrity. Further the drying process is much slower with zeolite than bentonite granules or activated charcoal. The faster drying is always not good in retention of seed quality. Similar results were reported by Ellis et al., (1991) in onion seeds were high germination up to three years observed when moisture content was maintained from 6.0 to 6.8 per cent (dry treatment) or 3.6 to 3.7 per cent (ultra dry treatment) and stored under a temperature of $2^{0}$ to $20{ }^{0} \mathrm{C}$. The onion seeds stored in glass container and aluminium foil with silica gel at $5{ }^{\circ} \mathrm{C}$ and $-20{ }^{\circ} \mathrm{C}$ retained germination of $90 \%$ and $76 \%$, respectively after seven years of seed storage (Doijode, 1995). Ellis et al., (1991) observed high germination up to three years in onion seeds when moisture content was maintained from 6.0 to 6.8 per cent (dry treatment) or 3.6 to 3.7 per cent (ultra dry treatment) and stored under a temperature of $2^{0}$ to $20^{\circ} \mathrm{C}$. Storage using desiccants like silica gel and zeolite beads maintained higher seed germination.

\section{Seedling vigour index}

The chilli seed stored with desiccant zeolite beads $\left(T_{1}\right)$ showed the highest vigour index (1097), bentonite granules $\left(T_{2}\right)(987)$, whereas vigour index of seed stored with bentonite granules $\left(T_{2}\right)$ and charcoal granules $\left(T_{3}\right)(920)$ were on par with each other. The seed stored under control without desiccants has showed lowest seedling vigour index (753) after 9 months of storage period (Table 2). The seeds stored with zeolite beads and silica gel maintained low moisture which might have resulted in lower respiration rate, lower metabolic activity and maintenance of higher seed vigour during storage. This lower moisture maintained in a airtight container might be responsible for higher germination, seedling length, seedling dry weight and seedling vigour indices as a result of greatly extending storage life as reported by Hong et al., (2005). In addition Padma and Reddy (2000) reported that onion seeds were dried with silica gel to $5.3 \%$ seed moisture content and stored in polythene bag maintained higher vigour index I with 474 after 20 months of seed storage compared to cloth bag 413 . Doijode (1995) observed high vigour index I and II of 591 and 162, respectively for the 
onion seeds stored in glass container with silica gel compared to 415 vigour index I and 113 vigour index II without silica gel.

\section{Moisture content}

The seed stored in airtight container with zeolite beads $\left(\mathrm{T}_{1}\right)$ and bentonite granules $\left(\mathrm{T}_{2}\right)$ showed the lowest seed moisture content throughout the storage period and were on par with each other. Zeolite beads $\left(\mathrm{T}_{1}\right)$ have reduce the initial seed moisture content from 8.50 to 4.30 per cent within first three months of storage and further it reduced to 4.00 per cent at end of nine months of storage period, whereas bentonite granules $\left(\mathrm{T}_{2}\right)$ reduced seed moisture content from 8.50 to 5.10 per cent.

The other treatments with charcoal granules $\left(\mathrm{T}_{3}\right)$ and control without desiccant $\left(\mathrm{T}_{4}\right)$ in airtight container reduced the seed moisture to 6.40 and 9.65 per cent, respectively. This may be due to highly polar surface within the pores which is main driving force for moisture adsorption from the seeds. Similar results on silica gel was reported by Vodouhe (2008) who dried three species of egusi seeds with silica gel and gave the lowest moisture content of (3.6 to $4.6 \%$ ) in Citrullus lunatus, (3.3 to $4.3 \%$ ) in Cucumeropsis edulis and (4.6 to $7 \%$ ) in Lagenaria siceraria seeds (Table 3).

Moisture content is the key factor for successful seed storage. In the current study, moisture content lowered with zeolite beads at ultra drying level i.e., below 3.6 per cent for 8 months and maintained the germination above seed certification standards. Storage of seeds of different species under slowly reduced moisture has been found to maintain viability for a longer period (Agrawal, 1982). Similarly, in Ammopiplanthus mangolica seed could be stored at ambient temperature $\left(25^{\circ} \mathrm{C}\right)$ with relatively low moisture content and their longevity decreased as seed moisture content increased (Yi et al., 2010).

\section{Electrical conductivity}

The electrical conductivity test measures the amount of electrolytes which leached out from the seed during imbibition is a sensitive index of seed quality (Hibbard and Miller, 1928) which showed negative association with seed germination.

In the present study, the electrical conductivity of seed leachate was negatively associated with the seed viability and vigour. In case of chilli seeds initial electrical conductivity $\left(0.451 \mathrm{dSm}^{-1}\right)$ was recorded and seeds stored with zeolite beads $\left(\mathrm{T}_{1}\right)$ has recorded significantly lowest electrical conductivity $\left(0.709 \mathrm{dSm}^{-1}\right)$ followed by bentonite granules $\left(\mathrm{T}_{2}\right)\left(0.727 \mathrm{dSm}^{-1}\right)$ compared to the other treatments. However, in activated charcoal granules $\left(\mathrm{T}_{3}\right)$ and control $\left(\mathrm{T}_{4}\right)$ treatments there was significant increase in the electrical conductivity of seed leachate values i.e. 0.788 and $0.874 \mathrm{dSm}^{-1}$, respectively at the end of storage (Table 4).

These results showed that slow leakage of intracellular substances (electrolytes and other solutes) which were responsible for maintenance of seed germination during storage. However, in control and activated charcoal showed significant increase in the electrical conductivity of seed leachate values during storage (Chen and Zhon, 1990). This may be due to the increase in the percentage of dead and abnormal seeds at different periods of storage. Effect of seed ageing on electrolyte leakage has been reviewed by several researchers who have found that as the ageing period increased, seed leachate of conductivity also increased in muskmelon seeds (Pesis and Timothy, 1983) and in tomato seeds (Coolbear et al., 1984). Penaloza and Eira (1993) have also reported that this might be the result of membrane repair during hydration process in tomato seeds. 
Table.1 Effect of desiccants on germination (\%) of chilli seeds

\begin{tabular}{|c|c|c|c|c|c|c|c|c|c|c|}
\hline Treatment & Initial & 1 month & 2 month & 3 month & 4 month & 5 month & 6 month & 7 month & 8 month & 9 month \\
\hline $\mathbf{T}_{1}$ & $\begin{array}{c}94.0 \\
(75.79)\end{array}$ & $\begin{array}{c}94.0 \\
(75.79)\end{array}$ & $\begin{array}{c}93.0 \\
(74.63)\end{array}$ & $\begin{array}{c}92.2 \\
(73.75)\end{array}$ & $\begin{array}{c}91.4 \\
(72.92)\end{array}$ & $\begin{array}{c}91.0 \\
(72.51)\end{array}$ & $\begin{array}{c}90.0 \\
(71.54)\end{array}$ & $\begin{array}{c}88.0 \\
(69.70)\end{array}$ & $\begin{array}{c}87.0 \\
(68.84)\end{array}$ & $\begin{array}{c}85.6 \\
(67.67)\end{array}$ \\
\hline $\mathbf{T}_{2}$ & $\begin{array}{c}94.0 \\
(75.79)\end{array}$ & $\begin{array}{c}94.0 \\
(75.79)\end{array}$ & $\begin{array}{c}92.4 \\
(73.97)\end{array}$ & $\begin{array}{c}91.6 \\
(73.12)\end{array}$ & $\begin{array}{c}91.0 \\
(72.51)\end{array}$ & $\begin{array}{c}88.6 \\
(70.24)\end{array}$ & $\begin{array}{c}87.6 \\
(69.35)\end{array}$ & $\begin{array}{c}86.6 \\
(68.50)\end{array}$ & $\begin{array}{c}84.8 \\
(67.03)\end{array}$ & $\begin{array}{c}84.0 \\
(66.40)\end{array}$ \\
\hline $\mathbf{T}_{3}$ & $\begin{array}{c}94.0 \\
(75.79)\end{array}$ & $\begin{array}{c}93.4 \\
(75.08)\end{array}$ & $\begin{array}{c}92.2 \\
(73.75)\end{array}$ & $\begin{array}{c}91.6 \\
(73.12)\end{array}$ & $\begin{array}{c}89.2 \\
(70.79)\end{array}$ & $\begin{array}{c}87.8 \\
(69.53)\end{array}$ & $\begin{array}{c}85.6 \\
(67.67)\end{array}$ & $\begin{array}{c}84.6 \\
(66.87)\end{array}$ & $\begin{array}{c}83.2 \\
(65.78)\end{array}$ & $\begin{array}{c}82.8 \\
(65.47)\end{array}$ \\
\hline $\mathbf{T}_{4}$ & $\begin{array}{c}94.0 \\
(75.79)\end{array}$ & $\begin{array}{c}93.4 \\
(75.08)\end{array}$ & $\begin{array}{c}91.0 \\
(72.51)\end{array}$ & $\begin{array}{c}89.4 \\
(70.97)\end{array}$ & $\begin{array}{c}87.6 \\
(69.35)\end{array}$ & $\begin{array}{c}86.0 \\
(68.00)\end{array}$ & $\begin{array}{c}84.2 \\
(66.55)\end{array}$ & $\begin{array}{c}81.0 \\
(64.13)\end{array}$ & $\begin{array}{c}77.6 \\
(61.73)\end{array}$ & $\begin{array}{c}75.4 \\
(60.24)\end{array}$ \\
\hline Mean & 94.0 & 93.7 & 92.2 & 91.2 & 89.8 & 88.4 & 86.9 & 85.1 & 83.2 & 81.9 \\
\hline S. Em. \pm & - & 0.64 & 0.63 & 0.82 & 0.77 & 0.63 & 0.62 & 0.84 & 0.81 & 0.89 \\
\hline C. D. $(\mathrm{P}=0.01)$ & - & NS & NS & NS & NS & 2.61 & 2.58 & 3.47 & 3.36 & 3.67 \\
\hline
\end{tabular}

Table.2 Effect of desiccants on seedling vigour index of chilli seeds

\begin{tabular}{|c|c|c|c|c|c|c|c|c|c|c|}
\hline Treatment & Initial & 1 month & 2 month & 3 month & 4 month & 5 month & 6 month & 7 month & 8 month & 9 month \\
\hline $\mathbf{T}_{1}$ & 1675 & 1561 & 1495 & 1410 & 1363 & 1320 & 1263 & 1193 & 1137 & 1097 \\
\hline $\mathbf{T}_{2}$ & 1675 & 1557 & 1471 & 1378 & 1329 & 1219 & 1162 & 1117 & 1059 & 987 \\
\hline $\mathbf{T}_{3}$ & 1675 & 1537 & 1438 & 1367 & 1270 & 1179 & 1115 & 1094 & 999 & 920 \\
\hline $\mathbf{T}_{4}$ & 1675 & 1502 & 1375 & 1256 & 1148 & 1065 & 1019 & 935 & 855 & 753 \\
\hline Mean & 1675 & 1539 & 1445 & 1353 & 1278 & 1196 & 1140 & 1085 & 1012 & 939 \\
\hline S. Em. \pm & - & 29.37 & 26.59 & 33.07 & 30.41 & 23.93 & 19.05 & 18.94 & 23.37 & 19.70 \\
\hline C. D. $(\mathrm{P}=0.01)$ & - & NS & NS & NS & 125.60 & 98.86 & 78.68 & 78.21 & 96.53 & 81.37 \\
\hline
\end{tabular}

Table.3 Effect of desiccants on moisture content (\%) of chilli seeds

\begin{tabular}{|c|c|c|c|c|c|c|c|c|c|c|}
\hline Treatment & Initial & 1 month & 2 month & 3 month & 4 month & 5 month & 6 month & 7 month & 8 month & 9 month \\
\hline$T_{1}$ & 8.50 & 5.50 & 4.70 & 4.30 & 4.20 & 4.10 & 4.00 & 4.00 & 4.00 & 4.00 \\
\hline $\mathbf{T}_{2}$ & 8.50 & 6.90 & 6.10 & 5.70 & 5.40 & 5.20 & 5.10 & 5.00 & 5.10 & 5.10 \\
\hline $\mathbf{T}_{3}$ & 8.50 & 7.30 & 6.60 & 6.20 & 6.10 & 6.00 & 6.10 & 6.20 & 6.31 & 6.40 \\
\hline $\mathbf{T}_{4}$ & 8.50 & 8.54 & 8.82 & 8.68 & 8.75 & 8.87 & 9.01 & 9.24 & 9.42 & 9.65 \\
\hline Mean & 8.50 & 7.06 & 6.56 & 6.22 & 6.11 & 6.04 & 6.05 & 6.11 & 6.23 & 6.34 \\
\hline S. Em. \pm & - & 0.15 & 0.13 & 0.12 & 0.11 & 0.09 & 0.08 & 0.07 & 0.05 & 0.04 \\
\hline C. D. $(P=0.01)$ & - & 0.60 & 0.53 & 0.48 & 0.44 & 0.36 & 0.33 & 0.31 & 0.20 & 0.17 \\
\hline
\end{tabular}

Values in parentheses are arcsine root transformed values, without arcsine indicate original values

$\mathrm{T}_{1}$ - Seed stored with zeolite beads $\quad \mathrm{T}_{2}$-seed stored with bentonite granules

$\mathrm{T}_{3}$ - Seed stored with charcoal granules $\quad \mathrm{T}_{4}$ - Seed stored in hermetic container without desiccant (control). 
Int.J.Curr.Microbiol.App.Sci (2018) 7(12): 2743-2751

Table.4 Effect of desiccants on electrical conductivity (dSm-1) of chilli seeds

\begin{tabular}{|c|c|c|c|c|c|c|c|c|c|c|}
\hline Treatment & Initial & 1 month & 2 month & 3 month & 4 month & 5 month & 6 month & 7 month & 8 month & 9 month \\
\hline $\mathbf{T}_{1}$ & 0.451 & 0.462 & 0.498 & 0.513 & 0.534 & 0.576 & 0.602 & 0.650 & 0.697 & 0.709 \\
\hline $\mathbf{T}_{2}$ & 0.451 & 0.483 & 0.510 & 0.527 & 0.546 & 0.591 & 0.624 & 0.571 & 0.716 & 0.727 \\
\hline $\mathbf{T}_{3}$ & 0.451 & 0.498 & 0.520 & 0.544 & 0.556 & 0.596 & 0.631 & 0.686 & 0.737 & 0.788 \\
\hline $\mathbf{T}_{4}$ & 0.451 & 0.512 & 0.575 & 0.612 & 0.665 & 0.706 & 0.752 & 0.788 & 0.814 & 0.874 \\
\hline Mean & 0.451 & 0.489 & 0.526 & 0.549 & 0.575 & 0.617 & 0.652 & 0.674 & 0.741 & 0.774 \\
\hline S. Em. \pm & - & 0.01 & 0.01 & 0.01 & 0.01 & 0.01 & 0.01 & 0.01 & 0.01 & 0.01 \\
\hline C. D. $(P=0.01)$ & - & 0.03 & 0.04 & 0.03 & 0.04 & 0.04 & 0.03 & 0.04 & 0.03 & 0.04 \\
\hline
\end{tabular}

Table.5 Effect of desiccants on dehydrogenase enzyme activity (OD Values) in chilli seeds

\begin{tabular}{|c|c|c|c|c|}
\hline Treatment & Initial & 3 month & month \\
\hline $\mathbf{T}_{\mathbf{1}}$ & 1.324 & 1.272 & 1.21 \\
\hline $\mathbf{T}_{\mathbf{2}}$ & 1.324 & 1.232 & 1.15 \\
\hline $\mathbf{T}_{\mathbf{3}}$ & 1.324 & 1.221 & 1.08 \\
\hline $\mathbf{T}_{\mathbf{4}}$ & 1.324 & 1.190 & 1.09 \\
\hline Mean & $\mathbf{1 . 3 2 4}$ & $\mathbf{1 . 2 2 9}$ & $\mathbf{1 . 0 0}$ & $\mathbf{1 . 1 1}$ \\
\hline $\mathrm{S}$ Em. \pm & - & $\mathbf{0 . 0 2}$ & $\mathbf{0 . 0 1}$ \\
\hline CD $(1 \%)$ & - & $\mathbf{N S}$ & $\mathbf{0 . 0 6}$ \\
\hline
\end{tabular}


Padma and Reddy (2004) noticed that okra seeds dried to $7.14 \%$ in silica gel in desiccator stored in polythene bags recorded less electrical conductivity of $329 \mathrm{~m} \mu \mathrm{hos} / \mathrm{cm}$ compared to cloth bag $361 \mathrm{~m} \mu \mathrm{hos} / \mathrm{cm}$ after 16 months of seed storage.

\section{Dehydrogenase enzyme activity}

It is measure of seed viability index and it was assessed through dehydrogenase enzyme activity. This was significantly influenced by desiccants during storage period. The initial dehydrogenase activity was (1.324) in chilli in seeds before storage. The highest dehydrogenase enzyme activity was observed with zeolite beads $\left(T_{1}\right)$ (1.149) followed by bentonite granules $\left(T_{2}\right)$ (1.092). The lowest dehydrogenase enzyme activity was observed in case of control $\left(\mathrm{T}_{4}\right)$ (0.924) and charcoal granules $\left(\mathrm{T}_{3}\right)$ (1.000). Ultra-dry seed storage is simple and inexpensive. Seeds can be dried in a desiccator until the correct moisture content is reached (silica gel and quicklime are ideal desiccants). Seeds can be stored in sealed containers at ambient temperature (Zheng et al., 1998) (Table 5).

The effects of dehumidification were associated with the recovery of the membrane and enzyme, which improved the ageingresistant capability of ultra-dried seeds. The results of this experiment showed that in the ultra-dried seeds, high activities of dehydrogenase, CAT, SOD and POD were kept. Free radical induced damage played a key role in seed deterioration during ageing (Pinhero et al., 1998). These results showed that the changes in activity of antioxidant enzymes are closely related to desiccation tolerance and the ultra-drying did not destroy the enzymes. The ultra-drying treatment can prolong the seed storage life by increasing dehydrogenase activity. The findings of this experiment showed that the lipid peroxidation was greatly suppressed under the ultra-dried condition. This implied that the enzyme systems were not destroyed but it was intact and high activities of antioxidant enzymes were kept in ultra-dry seeds.

The above research findings had resulted to conclude that the ultra-dry seed storage technology is the one of an ideal method to store seeds for longer period by using desiccants in an air tight container without seed quality reduction. Zeolite beads have professed advantages over other desiccants used in the present study, which include that they have higher regeneration capacity, greater affinity for water, particularly at low humidity. Moreover, the present results also indicated that chilli seeds drying by zeolite beads has reduced its moisture content to a desired level also maintained better seed quality parameters throughout the storage period. Hence, it is a suitable technology to low volume seeds, seed companies (either public or private) and seed banks to store precious seed material as well as plant genetic resources for a longer period.

\section{References}

Abdul-Baki, A. A. and J. D. Anderson. 1973. Vigour determination in soybean by multiple criteria. Crop Sci. 13: 630-637.

Agrawal, P. K. 1982. Viability of stored seeds and magnitude of seed storage in India. Seed Tech News. 12(1): 47.

Anonymous. 2014. International Rules for Seed Testing. Seed Sci. Technol. 27: 2530.

Anonymous. 2017. Horti. Stat. at a Glance, pp.64-86.

Chen, L. W. and Zhon, G. Q. 1990. Correlation between permeability of membranes and germination rate of rice seeds. Plant Physiol. 5: 36-38.

Coolbear, P., Francis, A. and D. Griesa. 1984. The effect of low temperature pre sowing treatments on the germination 
performance and membrane integrity of artificially aged tomato seeds. Expt. Bot. 35: 1609-1612.

Doijode, S. D. 1995. Effect of silica gel and storage containers on viability and vigour in onion. Seed Res. 18: 163-165.

Ellis, R. H., Hong, T. D. and E. H. Roberts. 1995. Survival and vigor of lettuce (Lactica sativa L.) and sunflower (Helianthus annuus L.) seeds stored at low and very-low moisture contents. Annals of Botany. 76: 521-534.

Ellis, R. H., Hong, T. D., Astely, D. and Kraak, H. L. 1991. Medium term storage of dry and ultra-dry seeds of onion at ambient and sub zero temperature. Onion News lett. Tropics. 6: 56-58.

Gomez, K. A. and Gomez, A. A. 1984. Statistical Procedures in Agricultural Research ( $2^{\text {nd }}$ edition). Cambridge Univ., New York. pp.680.

Harrington, J. F. 1972. Seed storage and longevity in: viability of seeds Ed. E. H. Roberts, Chapman and Hall Ltd. London, 1: 209-252.

Hibbard, R. P. and J. V. Miller. 1928. Biochemical studies on seed viability measurements of conductance and reduction. Plant Physiol. 3: 335-352.

Hong, T. D., Ellis, R. H., Astley, D., Pinnegar, A. E., Groot, S. P. C. and H. L. Kraak. 2005. Survival and vigour of ultra-dry seeds after ten years of hermetic storage. Seed Sci. Technol. 33: 449-460.

Kittoch, D. L. and A. G. Law. 1968. Relationship of seedling vigour to respiration and tetrazolium chloride reduction by germinating wheat seeds. Agron. J. 60: 286-288.

Padma, V. and Reddy, M. B. 2000. Effect of seed moisture and packaging material on onion seed longevity. Seed Res. 28(2): 171-175.

Padma, V. and Reddy, M. B. 2004. Storage of okra seed under ambient conditions. Seed Res. 32(1): 39-41.

Parsely, J. J. 1958. Relations of protoplast permeability to cotton seed viability and pre-deposition to seedling disease. Plant Disease Rep. 42: 582.

Penaloza, A. P. S. and M. T. S. Eira. 1993. Hydration dehydration treatments on tomato seeds [Lycopersicon esculentum (Mill)]. Seed Sci. Technol. 21: 309 -316.

Pesis, E. and J. N. Timothy. 1983. Viability, vigour and electrolyte leakage of muskmelon seeds subjected to accelerated ageing. Horti. Sci., 18: 242244.

Pinhero, R. G., Paliyath, G., Yada, R. Y. and D. P. Murr. 1998. Modulation of phospholipase and lipoxygenase activities during chilling: relation to chilling tolerance of maize seedlings. Plant Physiol. Biochem. 36: 213-224.

Roberts, E. H. 1972. Cytological, genetic and metabolic changes associated with loss of viability. Viability seeds. 32(2): 253306.

Singh, J., Govila, O. P. and Agrawal, P. K. 1988. Preliminary results from a study of seed germinability of pearl millet (Pennisetum tayphoides L.) $\mathrm{F}_{1}$ hybrid and their parents during accelerated aging test. Seed Sci. Technol. 16: 685695.

Vodouhe, R. S., Dako, G. E. A., Dulloo, M. E. and A. Kouke. 2008. Effects of silica gel, sun drying and storage conditions on viability of egusi seeds (Cucurbitaceae). Plant Genetic Resources Newslett. 153: 3642.

Wang X. F., Jing X. M. and Lin J. 2005. Starch mobilization in ultra dried seed of maize Zea mays L. during germination. J. integrated. Pl. Biol. 47:443-451.

Yi, L., Jian, J. Q. U., Wei-Min, Z., Li-Zhe, A. N., Peng, X. U. and Yong-Cai, L. 2010. 
Impact of ultra-dry storage on vigour capacity and antioxidant enzyme activities in seed of Ammopiptanthus mongolica. Bot. Studies. 51: 465-472.

Zhang, X. L. and Tao, K. L. 1988. Silica gel seed drying for germplasm conservation practical guidelines. Plant Genetic Resources Newslett. 75: 1-5.

Zheng, G. H., Jing, X. M. and Tao, K. L. 1998. Ultra dry seed storage cuts cost of gene bank. Nature. 393: 223-224.

\section{How to cite this article:}

Ninganna, J.S. Hilli and Vyakaranahal, B.S. 2018. Effect of Ultra-Dry Storage of Chilli Seeds. Int.J.Curr.Microbiol.App.Sci. 7(12): 2743-2751. doi: https://doi.org/10.20546/ijcmas.2018.712.311 